Crop Breeding and Applied Biotechnology S2: 121-130, 2012

Brazilian Society of Plant Breeding. Printed in Brazil

\title{
ARTICLE
}

\section{Contribution of the universities to the development of field crop cultivars}

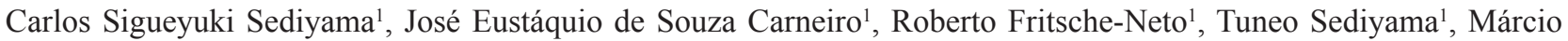
Henrique Pereira Barbosa ${ }^{1}$, João Carlos Cardoso Galvão ${ }^{1}$ and Moacil Alves de Souza ${ }^{1}$

Received 15 September 2012

Accepted 03 October 2012

\begin{abstract}
Public and private research institutions employ their best efforts to produce new cultivars, which are intended to ensure productivity, reduce ecological footprint and present characteristics that meet consumer expectations. Some Brazilian universities, which are usually originated from schools of higher education in agriculture, have contributed to the breeding of some crops. These universities also aimed to solve the problems of the Brazilian agricultural sector, and became essential tool to make Brazil an important player in the agribusiness world. In the last decades, regarding the five species presented here, the universities have developed 35 oat cultivars and made the country self-sufficient in this grain; they have also developed cultivars of common beans (27), sugarcane (59), soybean (62), and wheat (03), besides countless corn hybrids, since works in this species date before the establishment of the national cultivar registration system.
\end{abstract}

Key words: Avena sativa, Sacharum officinarum, Phaseolus vulgaris, Zea mays, Glycine max, Triticum.

\section{INTRODUCTION}

Commenting on the contribution of Brazilian universities to the production of new varieties of plants requires discussion about the process of evolution of agricultural education in Brazil, from the last years of the Empire until the first half of the twentieth century, when various universities were created. According to Azevedo (2005), the conditions and requirements of Brazilian society during that period led to the implementation, recognition and legitimacy of the agricultural school, which created a privileged site for the construction of a scientific and technical knowledge, which had been accumulated and applied in agricultural production, besides enabling the diffusion of knowledge and values proper to the routine of the parts involved in this production.

The transition of social relations based on slavery to relations of salaried production, the advent of the republican regime, based on the principle of federalism and economic liberalism, the consolidation of the State political power in the hands of the agrarian and commercial oligarchy, and the spread of positivist ideas about science proposed by part of the intellectual elite as way of promoting technical and social progress, are some important components of changes in the Brazilian society in the late nineteenth century. In this changing process, great value was added to education, in general, and to the teaching of applied sciences in particular.

However, according to Azevedo (2005), the situation of teaching did not change significantly, in legal terms, in relation to the legacy left by the Empire, given the fact that the 1891 Constitution omitted all the ideas related to a national education system. The Union continued regulating only secondary school, being the "Colégio Pedro II" a standard institution. On the other hand, higher education remained being controlled by the States, municipalities and by the private sector, whose implemented activities, with rare exceptions, did not have the support of public authorities. Thus, in the late nineteenth century, the preparatory secondary school prevailed, focused on meeting the needs of the privileged minorities in attaining higher education.

Higher education, in turn, maintained its academic and rhetoric vocation, without much concern for the practical and productive activities, thereby preserving the aristocratic cultural heritage. The persistence of these socio-economic conditions, along with the high cost for installation of farms with a high technological level, and the general prejudice against the applied education, in professional aspects, pointed out the social and political resistance to the enforcement of higher education in agriculture in Brazil.

\footnotetext{
${ }^{1}$ Universidade Federal de Viçosa (UFV), Departamento de Fitotecnia, 36.570-000 Viçosa, MG, Brazil. *E-mail: csediyama@ufv.br
} 
At the end of the Empire, it is noticed that there was only one agricultural institution of higher education in Brazil, the "Escola Agrícola da Bahia", located in São Bento das Lages, which was closed and, according to Capdeville (1991), there are indications that resources were allocated to the construction of "Estação Agronômica de Campinas", which was created in 1887 and converted, in 1892, to the "Instituto Agronômico de Campinas". Nevertheless, in 1883, the "Liceu Rio-Grandense de Agricultura e Veterinária" was founded in Pelotas, which in 1911 was renamed "Escola de Agronomia e Veterinária". However, despite the setbacks in the late nineteenth century, other four agronomy courses were created, conferring the title of agronomist: the "Escola Superior de Agronomia Taquariense", in Rio Grande do Sul, in 1896; the "Escola Politécnica do Rio de Janeiro", in 1896; the "Escola Politécnica de São Paulo", in 1898; and the "Escola de Engenharia de Porto Alegre", in 1897.

The agronomy course at the "Escola Politécnica de São Paulo" was extinguished and transferred, in 1910, to Piracicaba, in the State of São Paulo, which would host, from 1901, the "Escola Agrícola Prática de Piracicaba", whose construction started in 1891 and which, subsequently, became the "Escola Superior de Agricultura Luiz de Queiroz" (ESALQ) (Torres Filho 1926, Capdeville 1991). It is important mentioning another agriculture education institution originated in the first decade of the twentieth century, the "Escola Agrícola de Lavras", created in 1908.

Although schools have been designed to form agricultural technicians, both "Escola Agrícola Prática de Piracicaba" and "Escola Agrícola Prática de Lavras" were leveled to higher education, after the first decree that regulated the agronomic education in Brazil was edited, in 1910, being it due to the good facilities they held (laboratories, machinery, equipment, and experimental area) or by the duration and curriculum of both courses, and the level of excellence of most part of the professors. According to Coelho (1999), the differentiation between the secondary and higher education was tenuous, since the middle schools also had the function of supporting economic development in the region through scientific research and practical work in laboratories, experimental farms and the best methods of agriculture advertising, which, at first, was more appropriate to schools of higher education, as it would be institutionalized years later.

In the last two decades of the First Republic, there was a significant growth of Schools of Agronomy and/or Veterinary, which joined the four existing schools until then. Between 1910 and 1930, according to Capdeville (1991), 14 other Schools of Agronomy and/or Veterinary were created in Brazil.

In this scenario, quite unfavorable to the development of higher agricultural education, against the constraints events of the merely propaedeutic schools, on September $6^{\text {th }}$, 1920 , it was authorized the creation of the "Escola Superior de Agricultura e Veterinária" (ESAV), at Viçosa, in Minas Gerais. Inaugurated on August 28 $8^{\text {th }}, 1926$, it became the "Universidade Federal de Viçosa" in 1969 (Borges et al. 2006). With well-defined objectives, its first director, Dr. Peter Henry Rolfs, was hired so that the school would be established along with the lines of the Americans Land Grant Colleges, based on the trilogy of teaching, research and extension, aimed at agriculture and farmers problems. This model had shown great economic success in Southern and Midwestern U.S., particularly in the 1880 s. The adoption of this model at ESAV worked as one of the rare exceptions to the dominant academic teaching that prevailed in most higher education institutions in Brazil at that time (Borges et al. 2006).

There are documents that confirm that, from 1927, ESAV participated in exhibitions and in on-site exhibits of plants and crops in the state of Minas Gerais, which served as a mean of dissemination of new species that had been introduced and acclimated in that State, by Peter Henry Rolfs, as the production of dahlias, citrus fruit (grapefruit), avocados from Guatemala and sugarcane from Java (Bandeira 1996). Moreover, it was found a record on experiments and cultivation performed with some coffee cultivars.

According to Azevedo (2005), Diogo Alves de Mello, a Brazilian who studied and worked eleven years in the United States, took office in the Department of Agronomy of ESAV on May $17^{\text {th }}, 1927$, and soon developed cotton, bamboo, forest species, sweet potato, elephant grass, cowpea, fava beans, beans, tobacco and banana. He planted eight varieties of soybeans and found that 'Herman', 'Hoosier' and 'Biloxi' adapted better to the region. Professor Diogo Alves de Mello deserves special attention as a supporter of soybean crop in Brazil, a subject that he emphasized for all classes of technicians and agronomists to whom he taught. Also in the 1930s, Diogo Alves de Mello released the 'Agulha ESAV' rice cultivar, obtained by selection he performed on germplasm that existed near the campus, and established citrus crops with scientific basis, under the direction PH Rolfs.

The following discussion presents the contributions of some Universities in the improvement of oat, corn, sugarcane, beans, soybean and wheat. These species constitute substantive portion of Brazilian agribusiness.

\section{Beans}

In Brazil, researches with beans are performed primarily by public organizations, including research and education institutions at Federal and State level. In this context, the Universidade Federal de Viçosa (UFV) and Universidade Federal de Lavras (UFLA) are two of the most important for their continued scientific contribution in this area, not 
only in Minas Gerais, but also throughout the Country.

The bean research program at UFV, which started in 1955, was one of the first programs in this area in Brazil, and it is intertwined with the life history of Professor Clibas Vieira. In this institution, in the 1930s, there were some sporadic studies with this crop, which resulted in Mantuba cultivar developed by Professors O. A. Drummond, A. S. Muller and others, through the cross between Manteigão and Tubarão cultivars (Vieira 1996). Mantuba apparently had no great importance in agriculture, but went down in history as one of the first bean cultivars created by crossing in Latin America (Voysest 1983). In Brazil, it was certainly the first.

The study of cultivars and its breeding constituted the initial interest of Professor Clibas Vieira when, as a professor at UFV, he began researching bean crop in Minas Gerais, more specifically, in Zona da Mata region. It was an intensive work of collection, introduction and evaluation of germplasm. The first cultivars competition trial was installed on February $24^{\text {th }}, 1956$, and since then hundreds of trials have been conducted (Vieira 2005).

As a result of the first series of bean cultivars trials conducted in Minas Gerais, cultivars Rico 23, Manteigão Fosco 11 and Ricobaio 1014 have been recommended. The history of black beans 'Rico 23', told by Professor Clibas Vieira, deserves to be presented. The Professor reports (Vieira 2005):

\begin{abstract}
"When I was hired to work as an Assistant Professor of the Universidade Rural do Estado de Minas Gerais (UREMG), I had to clean up one of the rooms of the Agronomy Department to set up my office. During the cleaning, I found on a large table, hidden under a pile of dusty papers, a package containing a variety of black cowpea and another black bean, named "Rico", brought from Costa Rica by Paulo de Tarso Alvim. Evidently, the package had been thrown on the table and forgotten. That bean, now named 'Rico 23', once it was registered in my germplasm bank with this number, entered in the comparative trials of cultivars and excelled in such way that it was decided to include it in IANG's experiments, in which it also did well. In 1959, it was released as a new variety. It was tested in other States and its superiority was confirmed. From 1969 to 1972 it was recommended by the Comissão Brasileira de Feijão, linked to the Departamento Nacional de Pesquisa e Experimentação Agropecuária do Ministério da Agricultura for planting in seven States (RS, SC, PR, RJ, MG, ES and $G O)$. For some years it was heavily planted in Brazil, later replaced by better cultivars that emerged with the progress of breeding programs. Anyway, 'Rico 23'was for more than ten years a valuable contribution and it demonstrated that, in research, luck is also true."
\end{abstract}

Furthermore, as a result of yield comparative trials conducted in Minas Gerais, in collaboration with the Empresa de Pesquisa Agropecuária de Minas Gerais (EPAMIG), other 12 cultivars were recommended to the producers by the end of the 1990s (Vieira 2005). Many of these cultivars, used by producers in the past, were eventually replaced by others, especially by Carioca grain type cultivars which, over the years, dominated the producer and consumer markets not only in Minas Gerais, but also in other States in Brazil.

It is noteworthy that, until the late 1990s, the majority of bean cultivars recommended in Minas Gerais were from introductions, being most lines derived from the Centro Internacional de Agricultura Tropical (CIAT). With the development of national programs, which started to develop their own lines, there was a drastic change in this scenario. Currently, the recommended cultivars are derived from crosses made in Brazil.

Since the early 1990s, the bean breeding program at UFV has used hybridization as a strategy to develop its own lines. It was a joint effort of the professors of the Department of Plant Science and Instituto de Biotecnologia Aplicada à Agropecuária (BIOAGRO). Additionally, several studies have been conducted at BIOAGRO in order to understand the inheritance of resistance to different pathogens, and especially to identify molecular markers RAPD (Random Amplified Polymorphic DNA) and SCAR (Sequence Characterized Amplified Region) linked to alleles for resistance to specific pathotypes of fungi that cause anthracnose, angular leaf spot and rust (Alzate-Marin et al. 2001).

The Universidade Federal de Lavras (UFLA) started its research work with bean crop in 1968 (Matos 2005), assessing lines introduced from other regions. The biggest boost in research occurred in 1971, with the hiring of Professor Magno A. P. Ramalho, and since then it has contributed to the improvement of bean, and also to study the management of this crop. Similar to Professor Clibas Vieira, Professor Ramalho is a great enthusiast of this crop with supporters all over Brazil. The growth of bean breeding program at UFLA occurred, according to the reports of Professor Ramalho, with the hiring of Professor João Bosco dos Santos, in 1976, and the inclusion of the researcher Ângela de Fátima Barbosa Abreu, in 1984, besides the creation of the Graduate Program in Agronomy, in the area of Genetics and Plant Breeding, in 1986.

At first, works at UFLA focused on the selection of pure lines derived from cultivars used by farmers in the region. One of these selections resulted in the release of ESAL-1 cultivar, in 1984 (Zimmermann et al. 1996), remaining in cultivation for several years in Minas Gerais and also in the State of Espírito Santo. As one might expect, the program had greater emphasis on basic research, aiming at improving the efficiency of the selection process. In this context, research on bean, especially in breeding, provided great contribution to human resource training and knowledge generation. However, the development of lines aiming at recommending new cultivars was always one of UFLA's 
objectives. During the past 40 years, several lines have been obtained, some of them recommended as cultivars (Abreu et al. 2004, MAPA 2012) and others used in crosses for several breeding programs in Brazil.

One of the steps of great importance and difficulty in a breeding program is the evaluation of lines in representative environments of the production areas in order to recommend cultivars for producers. This is more evident in university programs, given the commitments of the professors with the teaching and guidance of students, both undergraduate and graduate. In this context, the partnerships established in the State of Minas Gerais, involving UFV, UFLA, EPAMIG and Embrapa, were crucial and responsible for the success of the recommendation of bean cultivars in this State. As a result of this work, several cultivars have been recommended (Zimmermann 1996, MAPA 2012). Over the past decade, according to the RNC - Registro Nacional de Cultivares (MAPA 2012), eight new bean cultivars have been recommended: Ouro Vermelho, BRSMG Talismã, BRSMG Pioneiro, BRSMG Majestoso, BRSMG Madrepérola, BRSMG Realce, BRSMG Tesouro and BRSMG União.

The Common Bean Program of the State of Minas Gerais is a good example of cooperative effort that worked both in Lavras and Viçosa. EPAMIG and EMBRAPA, through their researchers, work closely with professors of UFV and UFLA, so that the recommendation of bean cultivars in the State of Minas is made with great harmony. Collaboration of this nature, between State and Federal agricultural research entities and Federal Universities, is unusual in Brazil and with rare exceptions happens in other States.

\section{Corn}

The history of teaching, research and extension with corn, somehow, is intertwined with the history of the Universidade Federal de Viçosa (UFV). The first paper about this crop, published by a faculty member at the institution, occurred three years after its creation, in 1929, by Peter Henry Rolfs, first director of the "Escola Superior de Agricultura e Veterinária" (ESAV) and considered the mastermind of this University (Azevedo 2005). In 1931, the First Corn Exposition occurred at UFV (Bandeira 1996), and in 1935, under the guidance of Professor Diogo Alves de Mello, it was planted the first field of hybrid corn in the country, using as parental lines originated from 'Catete' and 'Prolifico Branco' cultivars. The following year, 1936, Professor Antônio Secundino de São José planted hybrid seeds which yielded 5,300 kilos per hectare which at that time was a record. With further work, using other cultivars, and new successes, the hybrids were very well accepted by farmers, and the School began selling its seeds.

In 1938, after a training period in the US, Professor
Antonio Secundino brought a collection of lines and crosses, which was completely unsuitable for our tropical conditions. He also brought the open-pollinated variety Tuxpan Yellow Dent, developed by Dr. P. C. Mangelsdorf (Viegas and Krug 1952). From this variety, several lines have been developed, with others derived from national cultivars 'Catete', 'Xavier', 'Amarelão' - and others, allowed the composition of the first commercial hybrid in Brazil. Based on these results, in 1944, Professor Secundino published the paper "O milho - como produzí-lo melhor e mais barato" (Corn-how to produce it better and cheaper), in which the novelty of hybrid corn in Brazil was presented.

In the following year, on September $19^{\text {th }}, 1945$, Secundino along with Dr. Dee William Jackson, John Ware, Gladstone Drummond and Adylio Vitarelli, created a company dedicated to experimenting with hybrid corn: "Agroceres Ltda.". In 1951, after a merger with a foreign company, it became "Sementes Agroceres S/A".

In 1950, Secundino published in Revista Ceres, the manuscript "Hybrid Corn". The Professor emphasizes, in a language understandable by lay people, how one can obtain corn hybrids. In this paper, aiming to highlight the benefits of this new technology, Secundino compares the hybrid vigor observed in corn with the one obtained in the crossing between a donkey and a mare for obtaining a mule.

Among other institutions, the Universidade Federal de Lavras (UFLA), in the 1920s, also had great participation in corn breeding in Brazil, which culminated with the publication of two books, the first being about the culture and its breeding in Brazil, and the second about genetics and plant breeding, published by Hunnicutt and Paiva in 1924 and 1925, respectively (www.redetec.org.br/inventabrasil/milhoh.htm).

Meanwhile, the Escola Superior de Agricultura Luiz de Queiroz (ESALQ), especially through the work of Ernesto Paterniani, John Rubens Zinsly and Roland Vencovsky, developed studies on breeding methods and even commercial cultivars, having collected, evaluated and preserved a huge collection of races and cultivars of corn. The development of works on corn population breeding at ESALQ began in the 1960s, being the first cultivars released in the 1970s, of which Centralmex, Dentado Composto and Flint Composto stand out (www.redetec.org.br/inventabrasil/ milhoh.htm).

It is noticed that the history of corn breeding in Brazil is similar with what happened in American universities. Thus, teams that were formed here could practice and convey knowledge that built support methodologies and human resources of ongoing breeding programs in Brazil (www.milho.ufv.br).

In recent years, universities continued developing hybrids, for instance, it can be cited UFVM 100, UFVM 200 and UFVM 2 cultivars, from UFV. More recently, it has been 
released at UFLA the double-hybrid UFLA JM100, and in the Universidade Estadual do Norte Fluminense (UENF), UENF 01 and UENF 14 popcorn cultivars. Nevertheless, the participation of universities in the corn seed market has been declining year after year. Today, corn cultivars from universities do not represent more than 1 to $2 \%$ of the planted area in Brazil (www.cnms.embrapa.br), which is too little compared to the almost $100 \%$ of participation in the beginning of the last century. The main factor contributing to the reduction of the participation of universities in the development of corn cultivars was the increased participation of multinational companies in breeding and seed production of the species. Additionally, with the technology of transgenic, cultivars that do not present events are not interesting to most farmers, even to small farmers, who use low-tech, or live on cultivating marginal areas.

Given this scenario and being encouraged by the Innovation Law, it would be appropriate to follow the North American trend, in which there are strong partnerships between universities and large multinational companies.

Another point is to consolidate, strengthen and improve the training of human resources for current and new research needs. According to Professor Claudio Lopes de Souza Jr. (ESALQ / USP), "Universities do not meet the demands of public and private companies for qualified professionals in the field of plant breeding." However, if there is no interest by the government to invest in teaching, research and extension, this lag will remain unsolved.

\section{Oats}

Oat cultivars (Avena sativa L.) grown in southern Brazil until the beginning of the 1980s were imported from Uruguay and Argentina (Barbosa Neto et al. 2000). These genotypes did not adapt well to the new environment, especially because of their long cycle and excessive plant height. The lack of adaptation determined reduced productivity and poor grain quality. Thus, in the early 1970s, the "Universidade Federal do Rio Grande do Sul" (UFRGS) and the "Universidade de Passo Fundo" (UPF) started breeding programs for this culture by introducing lines and segregating populations from the University of Wisconsin (Federizzi et al. 1997). This initial effort led to the release of several improved cultivars during the $1980 \mathrm{~s}$.

Until 1998, this second step resulted in the release, by UFRGS and UPF, of approximately 35 superior cultivars of oats, on a commercial scale. Barbosa Neto et al. (2000) estimated the genetic progress in oat breeding programs of southern Brazil and the results indicated linear gain for heading date, grain yield, grain weight and test weight. Oat breeding programs in southern Brazil, although they have not reached the maximum level, they have been effective in producing new cultivars with higher productivity and grain quality and superior agronomic traits. The most recent cultivars are URS Guria, URS Charrua, URS torena, URS Corona and URS FAPA Slava.

In the same way, the "Universidade Federal de Pelotas" (UFPel), represented by its Genomic and Plant Breeding Center (CGF/FAEM/UFPel), in partnership with PróSementes Foundation, has just taken another important contribution to Brazilian oat crop, integrating two new oat cultivars to the National Cultivar Registry (RNC): FAEM Carlasul and FAEM Chiarasul.

These cultivars joined three others that had already been developed by the group: Albasul, Barbarasul and Brisasul cultivars. The five released cultivars are part of the results of the breeding program efforts of the CGF/FAEM/UFPel, which since 1995 have been working on the development of superior oat genotypes, under the coordination of Fernando Irajá Félix de Carvalho and Antonio Costa de Oliveira, and, with the retirement of the first, in 2008, Luciano Carlos da Maia took over the breeding work.

This important center has decisively contributed in research and professional training related to the basic and applied studies in the areas of plant breeding and biotechnology. Among the most significant contributions, it can be cited the rice genome sequencing and annotation of the genome of Brachypodium distachion, a wheat related model species.

In relation to the performance in oat research, the Center has integrated, since 1998, the research network called Brazilian Oat Research Committee (CBPA), which defines and ponders the release of new genetic constitutions in the market, besides being an important way of exchanging information and research materials. Moreover, in its $31^{\text {st }}$ Meeting, which was held last April, the CGF released the FAEM Dilmasul cultivar, which is in the process of registration and production of basic seeds for distribution to seed producers.

The partnership between UFPel and Pró-Sementes Foundation has provided agility to the process of offering seeds of improved cultivars developed by the breeding program to producers; contribution to the human resource training; and narrower link between public and private sectors.

\section{Soybean}

Soybean has been cultivated for over five thousand years in Asia. Its cultivation has expanded through ancient China, becoming the staple food of the population, but for some thousand years, it was restricted only to that country. In the seventeenth century, it began to be spread to other parts of Asia, such as India, Ceylon, Malaysia, etc., reaching Europe in the eighteenth century. In 1804, early XIX century, there is the first reference of soybeans in the United States, in the 
region of Pennsylvania (Sediyama et al. 1985).

In Brazil, the experience with soybean, made in Bahia in 1882, appears to be the earliest reference. In São Paulo, the first soybeans were introduced through the Instituto Agronômico de Campinas (IAC), in 1889, by Franz W. Dafert. In 1899, Gustavo D’Utra, after studying this plant, published the first work entitled "Nova cultura experimental de soja" (New experimental soybean crop). In 1900, soybean seeds were delivered by the Institution to the Secretariat of Agriculture for distribution to farmers interested in cultivating this legume. In Rio Grande do Sul, it was first introduced in 1914 by F.C. Craig, from Escola Superior de Agronomia e Veterinária, in Pelotas, Rio Grande do Sul (Miyasaka 1954, Silva 1954, Williams 1955, Miyasaka et al. 1970, Mascarenhas 1983, Sediyama et al. 1983, Sediyama et al. 1985).

The expansion of soybean, according to Sediyama et al. (1985), in contrast to the antiquity of its use by the oriental people, only occurred in other regions of the globe, both in planting and in consumption, in the early twentieth century. After 1925, through the efforts of U.S. technicians, who studied soybeans in many ways: agricultural, industrial, nutritional and economical, there was a significant increase in world production. In the period of 1967-74, world production of this legume was strongly increased, from 38 million tons to around 63 million. This increase was due to the strong participation of the United States and Brazil, since China kept its production at around 10 million tons.

As reported by Sediyama et al. (1985), soybean underwent a great expansion in several Brazilian states. After 1947, this crop became economically important in Rio Grande do Sul, supported by the high usage of in natura legumes to feed pigs, for being an excellent protein source. With the increase in production, industries were created and the exports began. In the state of Paraná, this culture boosted after 1954 as a result of an intense frost that happened in 1953.

Originally from Asia, in latitudes between 28-50 (Hartwig 1973), the expansion of soybean cultivation in Cerrado of Central Brazil, i.e., at low latitudes, occurred mainly due to breeding and research in various areas of soybean production chain carried out by the Instituto Agronômico de Campinas (IAC) and the Universidade Federal de Viçosa (UFV), after the 1950s (Miyasaka 1954, Silva 1954, Miyasaka et al. 1970, Mascarenhas et al. 1983, Sediyama et al. 1983, Sediyama et al. 1985).

Several soybean cultivars had already been recommended for grain production in Minas Gerais by the 1920s, and mostly have been brought by Japanese immigrants from their country of origin, and constituted in excellent germplasm for initial breeding works. During 1956/57, detailed studies of the behavior of cultivars in this State started to be conducted by the Universidade Federal de Viçosa (Brandão 1961). In the early 1960s, soybean had already been spread in different regions of the State and there was a great number of varieties in cultivation, such as Abura, Aliança, Amarela Grande, Biloxi, Cherokee, CNS, Ebony, Edna, Mammoth Yellow, Mogiana, Otootan, Paraguaia, Pereira Barreto, Santa Maria e Yandra (Brandão 1961).

However, soybean breeding program of this University (Sediyama et al. 1983, Sediyama et al. 1985) had its start consolidated in 1963, with the contribution of the American researchers Marvin L. Swearingin and Kirk L. Athow, when hundreds of cultivars and lines coming mainly from the Southern United States were introduced in Viçosa. During $1964 / 65$, it was made effective the intense work in selection and new introductions. In 1966, 1967 and 1968, many crossings were carried out among the best selected genotypes, in order to develop cultivars better adapted to the Central Brazil. In 1969, with the participation of Professor Tuneo Sediyama, two soybean cultivars were released, Viçoja and Mineira (Swearingin and Sediyama 1969a, b), which were widely planted in São Paulo, Paraná and Mato Grosso do Sul. In 1973, it was released the third variety, UFV-1, which contributed, until the mid-1980s, for the consolidation of soybean production in the Cerrado of Central Brazil, having been grown in considerable proportions, especially in Minas Gerais, Goiás, Mato Grosso, São Paulo and Mato Grosso do Sul. In the subsequent years, other cultivars have been released, including for the State of Espírito Santo.

The first official recommendation of soybean cultivars to Minas Gerais, considering the different soil conditions, was made in 1973, when 'IAC-1', 'IAC-2', 'Industrial', 'Pelicano' and 'Santa Rosa', developed by IAC, and 'Mineira', 'Viçoja' and ' UFV-1', developed by UFV, have been recommended (Arantes and Rao 1982).

Although soybeans have initially been grown on more fertile soils, crop productivity was very low, since the State did not have its own technology for this crop. Over the years, new technologies have been generated and crop productivity has consistently been growing. Among all the technologies developed, the responsible for this significant increase in grain yield was, undoubtedly, the release of more adapted and productive cultivars, which rose from $441 \mathrm{~kg} \mathrm{ha}^{-1}$ in the five-year period $1960-65$ to $2,008 \mathrm{~kg} \mathrm{ha}^{-1}$ in 1986-88, representing a cumulative increase of $355.4 \%$.

It is known that cultivars developed for the regions situated between latitudes $28-50^{\circ}$, when cultivated in tropical or subtropical regions, i.e., at low latitudes $\left(0-28^{\circ}\right)$, have their productivity reduced, mainly as a consequence of the limited vegetative growth, occasioned by the length of photoperiod. This fact has generated the need for the 
creation of cultivars adapted to tropical and subtropical regions. The work conducted by IAC and UFV, in the 1960s and 1970s, provided the obtaining of cultivars less sensitive to photoperiodism, making possible the expansion of soybean in Brazilian Cerrado and regions close to the Equator Line. In the 1970s, soybean breeding began at Empresa Brasileira de Pesquisa Agropecuaria - EMBRAPA. Since then, other institutions, such as Empresa Goiana de Pesquisa Agropecuaria - EMGOPA, Empresa de Pesquisa Agropecuaria de Minas Gerais - EPAMIG, FT - Pesquisa e Sementes, Empresa de Pesquisa Agropecuaria e Extensão Rural - EMPAER, Centro de Pesquisa Agropecuaria do Cerrado - CPAC and other institutions have contributed to the development of new cultivars.

In the 1980s, UFV included in the objectives of its breeding program the quality improvement of soybeans for human consumption, including better taste, levels of oil and protein, elimination of antinutritional factors, reduction of polysaccharides, altered levels of unsaturated fatty acids and others (Pereira et al. 1992, Araújo et al. 1997, Moreira et al. 1997, Utumi et al. 1998, Chiari et al. 2004, Lanna et al. 2005, Sediyama et al. 2005, Moraes et al. 2006, Barros et al. 2008, Barros et al. 2012, Teixeira et al. 2012). Simultaneously, the use of biotechnology tools became part of the routine in the work of soybean breeding (Alzate-Marin et al. 1996, Moreira et al. 1997, Schuster et al. 2001, Moraes et al. 2006). Moreover, it is noteworthy that the introduction of these tools allowed to obtain cultivars so that Brazilian farmers could get rid of problems caused by diseases that attacked severely soybean crops in the decades of 1990 and 2000, such as the appearance of Asian rust (Phakopsora pachyrhizi), stem canker (Diaporthe phaseolorum f. sp. Meridionalis / Phomopsis phaseoli f. sp. Meridionalis) and cyst nematode (Heterodera glycines), and frequent breakage of resistance to diseases that are commonly present in crops (Brito et al. 1999, Diogo et al. 2000, Schuster et al. 2001, Carvalho et al. 2002, Martins et al. 2002, Martins Filho et al. 2002, Cervigni et al. 2004, Gravina et al. 2004, Freire et al. 2008, Matsuo et al. 2011).

In the 2000s, two more lines of research were introduced: quality improvement of soybean oil for biodiesel production (Santos et al. 2012) and soybean breeding for animal feeding, in the form of hay or silage (Mello 2006, Souza 2011). In 2011, UFV accounts for 58 cultivars created by the Institution, of which 33 are registered or protected in the Serviço Nacional de Proteção de Cultivares (SNPC), an agency linked to the Ministry of Agriculture, Livestock and Supply of Brazil.

It should be noted that, besides the production of new cultivars, UFV, through its -Graduate Programs in Plant
Science and in Genetics and Breeding, has contributed to the formation of hundreds of soybean breeders, who employ their expertise in private or public institutions that work on soybean breeding in Brazil and abroad.

In recent years, the Universidade Federal de Uberlândia has made available to farmers four soybean protected at SNPC cultivars created by that Institution.

\section{Sugarcane}

The contribution of universities in improving sugarcane is discussed in more detail by Barbosa et al. (2012). Currently, the improvement of sugarcane in universities is conducted by the Rede Interuniversitária para o Desenvolvimento do Setor Sucro-energético - Ridesa (Interuniversity network for the development of the sugar and energy sector). This network has no legal personality and it consists of the partnership of ten Federal Universities. It was originally formed in 1990 by the Universidade Federal do Alagoas (UFAL), Universidade Federal Rural Pernambuco (UFRPE), Universidade Federal de São Carlos (UFSCar), Universidade Federal do Rio de Janeiro (UFRRJ) and Universidade Federal de Viçosa (UFV). In 1992, it incorporated the Universidade Federal do Paraná (UFPR) and the Universidade Federal do Sergipe (UFS); in 2003, the Universidade de Goiás (UFG); and, in 2008, the Universidade do Mato Grosso (UFMT) and the Universidade do Piauí (UFPI). Its network-management model involves, among other things, the public-private partnership (universities and sugar and alcohol industries) for the development of cultivars.

Ridesa has produced 59 varieties of sugarcane since 1990 and it is now responsible for $59 \%$ of the total area cultivated with this crop in Brazil. In the last five years, 286 agronomists were trained in sugarcane breeding programs of the universities that comprise Ridesa, as an internship, specialization course or scientific initiation. Since 2007, the network has formed 35 Masters, 24 Doctors and seven Post-Docs, who developed researches related to sugarcane genetic improvement. Dias (2011) reports that the Brazilian sugarcane breeding programs have released 111 sugarcane cultivars, as registered by the Ministry of Agriculture and that, in relation to ethanol, only in the last decade (20002009 ), the new cultivars were responsible for $20.8 \%$ of yield gain of ethanol per hectare.

\section{Wheat}

It is believed that wheat, as it is known today, came originally from wild grasses, which were developed near the Tigris and Euphrates rivers (Asia), around 10,000 to 15,000 years BC. Worldwide it is the second most-produced cereal after maize and with rice being the third. However the earliest records date from the year of $550 \mathrm{BC}$, it is believed that it has 
been cultivated for over 11,000 years. The primitive wheat had very fragile ears, which broke easily when ripe. A more fragile rachis allowed the ear to easily shatter and disperse the spikelets. It took many years of natural and artificial selection to reach the currently known types of wheat (Silva 1996).

According to Bered et al. (2000), the story of wheat in Brazil began in 1534, when the ships of Martim Afonso de Souza brought the first seeds to be sown in the lands of the Captaincy of São Vicente, which disseminated to all other captaincies. Brazilian wheat fields anticipated to Americans, Argentines and Uruguayans, since Brazil was the first American country to export wheat, thanks to the crops maintained in São Paulo, Rio Grande do Sul and other regions. After 1940, the culture started to expand commercially in Rio Grande do Sul. In that time, colonists from southern Paraná planted wheat seeds brought from Europe in relatively poor soils where taller and aluminum toxicity tolerant cultivars showed better adaptation.

In 1912, the Ministry of Agriculture created the first experimental field of wheat in Rio Grande do Sul. In 1919, the Estação Experimental de Ponta Grossa, PR, and the Estação Experimental de Alfredo Chaves, today Veranópolis, RS, were created. In the latter, the Czech agronomist Carlos Gayer worked between that year and 1924, whose main merit was for having collected the old varieties grown in the colonial zone. In genetic improvement of wheat it is highlighted the researcher Iwar Beckman, hired by the Ministry of Agriculture, making the year of 1924 a milestone in genetic improvement of wheat in southern Brazil. Several lines studied by Carlos Gayer stood out and are known as Alfredo Chaves lines, making part of the "pedigree" of all varieties grown in Brazil today (Cunha 2001).

In Paraná, the first initiatives for improvement of wheat occurred in 1914 at the Estação Experimental de Ponta Grossa..

The per capita consumption of wheat flour, in Brazil, has surpassed that of milled rice ready for consumption. Despite the importance of wheat as food for Brazilian people, domestic production historically meets only $50 \%$ of consumption, which makes Brazil a traditional wheat importer. This lack of domestic production over consumption has been a matter of constant concern of government agencies, searching for solutions to increase domestic production of wheat. In this context, the genetic improvement of wheat is the main alternative to develop cultivars adapted to wheat growing regions of Brazil, which includes the states of Rio Grande do Sul, Santa Catarina, Paraná, Mato Grosso do Sul, Goiás, Minas Gerais, Distrito Federal, Mato Grosso and Bahia, and it requires integrated efforts of public and private institutions to meet the needs for improvement and development of new cultivars.
In the 1920 s, due to the need to expand the cultivation of wheat in the country, it was created a program of support by the Federal Government and researches were intensified in several regions, including Paraná, São Paulo and Minas Gerais. After 1969/70, wheat expanded to areas of more fertile soils in the north and west of Paraná and, in 1979, the State took the lead in wheat production in Brazil. In 1986/87, in an area of 3,456 million ha, Brazil produced 6 million tons of wheat, while Paraná, in that season, produced three million tons of wheat, and yield reached $1,894 \mathrm{~kg} \mathrm{ha}^{-1}$.

It is noteworthy the important work in research of Federal and State institutions, such as the Instituto Agronômico do Sul - IAS, the Instituto Agronômico de Campinas - IAC, the Instituto Agronômico de Minas Gerais - IAMG, and the Instituto de Pesquisa e Experimentação Agrícola do Centro-Oeste - IPEACO, among others. During the 1970s, Federal institutions were incorporated to Embrapa, evidencing, in wheat improvement, Embrapa Trigo at Passo Fundo, Embrapa Centro Oeste at Dourados and Embrapa Cerrados at Planaltina. At the same time, some state institutions had significantly participations, such as EPAMIG, IAPAR, EMPASC, IAC, and private institutions, such as OCEPAR and FECOTRIGO, linked to cooperatives in Paraná and Rio Grande do Sul. Recently, private sector companies have been developing genetic improvement of wheat, and several cultivars are used by the farmers, especially in the states of Paraná and Rio Grande do Sul. Currently, some associations have obtained in successive years averages exceeding $2,500 \mathrm{~kg} \mathrm{ha}^{-1}$. Wheat yields exceeding $6,500 \mathrm{~kg}$ $\mathrm{ha}^{-1}$ are frequently reported in well-managed crops.

By checking the ratio of wheat cultivars that have been released since 1900 , it is clear that the majority comes from State and Federal research institutions. It is discreet the participation of Higher Education Institutions in producing wheat cultivars in Brazil. However, universities have played an important role in the development of basic research and methodologies that improve the efficiency of breeding programs and especially in the training of professionals who integrate the breeding teams at research institutions.

Research on wheat at the Universidade Federal de Viçosa have being done for long, but the breeding program of this species only began in 1993. Since then, UFV has contributed to the release of three wheat cultivars for Central-Brazil: 'Aliança', 'Brilhante' and 'UFT 1 - Pioneiro'. These releases resulted from the integrated work between UFV, EPAMIG, Coopadap (Cooperativa dos Agricultores do PADAP) and Embrapa. Besides the improvement of the final product, which results in producing cultivars for use by farmers, the Wheat Research Program at UFV led to the conclusion at graduate level of 11 masters and seven doctoral dissertations. 


\section{Contribuição das universidades ao desenvolvimento de cultivares de grandes culturas}

Resumo - Inúmeras instituições, públicas e privadas, empregam seus melhores esforços para produzir novas cultivares, as quais têm por objetivo garantir a produtividade, reduzir insumos e apresentar características que atendam às expectativas dos consumidores. Algumas universidades brasileiras, em geral originadas de escolas de ensino superior de agricultura, têm contribuido para o melhoramento genético de algumas culturas. Essas universidades também visavam resolver os problemas do setor agropecuário brasileiro, e se tornaram instrumento fundamental para alçar o Brasil como um respeitável ator do agronegócio mundial. Nas últimas décadas, considerando as cinco espécies aqui apresentadas, as Universidades desenvolveram 35 cultivares de aveia branca e tornaram o país autossuficiente nesse grão; desenvolveram 27 cultivares de feijoeiro, 59 de cana-de-açúcar, 62 de soja, 03 de trigo, além de inúmeras e incontáveis cultivares de milho, pois os trabalhos nesta espécie datam muito antes dos registros nacionais de cultivares.

Palavras-chave: Avena sativa, Sacharum officinarum, Phaseolus vulgaris, Zea mays, Glycine max, Triticum.

\section{REFERENCES}

Abreu AFB, Ramalho MAP, Carneiro JES, Gonçalves FMA, Santos JB, Del Peloso MJ, Faria LC, Carneiro GES and Pereira Filho IA (2004) "BRSMG Talismã": common bean cultivar with Carioca graintype. Crop Breeding and Applied Biotechnology 4: 372-374.

Alzate-Marin AL, Arruda MC, Correa RX, Nietsche S, Carvalho GA, Faleiro FG, Sartorato A, Ferreira C, Barros EG and Moreira MA (2001) Marcadores moleculares ligados a genes de resistência identificados no programa de melhoramento do feijoeiro do Bioagro/UFV. In I Congresso brasileiro de melhoramento de plantas. SBMP, Goiânia (CD-Rom).

Alzate-Marin AL, Baía GS, Martins Filho S, Paula Júnior TJ, Sediyama CS, Barros EG and Moreira MA (1996) Use of RAPD-PCR to identify true hybrid plants from crosses between closely related progenitors. Brazilian Journal of Genetics 19: 621-623.

Arantes NE and Rezende AM (1982) Cultivares de soja para Minas Gerais - 1982. Informe Agropecuário 8: 24-28.

Araújo JMA, Carlos JCS and Sediyama CS (1997) Isoflavonas em grãos de soja: Importância da atividade de $\beta$-glicosidase na formação do sabor amargo e adstringente. Ciência e Tecnologia de Alimentos 17: 137-141.

Azevedo DS (2005) Melhoramento do homem, do animal e da semente. O projeto político pedagógico da Escola Superior de Agricultura e Veterinária do Estado de Minas Gerais (1920-1948): Organização e Funcionamento. Universidade de São Paulo, São Paulo, 220p.

Bandeira LA (org.) (1996) UFV 70 anos - a trajetória da Escola de Viçosa. Universidade Federal de Viçosa, Viçosa, 110p.

Barbosa MHP, Resende MDV, Dias LAS, Barbosa GVS, Oliveira RA, Peternelli LA and Daros E (2012) Genetic improvement of sugar cane for bioenergy: the Brazilian experience in network research with RIDESA. Crop Breeding and Applied Biotechnology S2: 87-98.

Barbosa Neto JF, Matiello RR, Carvalho FIF, Oliveira JMS, Pegoraro DG, Schneider F, Sordi MEB and Vacaro E (2000) Progresso genético no melhoramento da aveia-branca no sul do Brasil. Pesquisa Agropecuária Brasileira 35: 1605-1612.

Barros BA, Silva WG, Moreira MA and Barros EG (2012) In silico characterization and expression analysis of the multigene family encoding the Bowman-Birk protease inhibitor in soybean. Molecular Biology Reports 39: 327-334.

Barros JGA, Moraes RMA, Piovesan ND, Barros EG and Moreira MA (2008) Efeito do inibidor de protease Kunitz sobre níveis de lipoxigenases em sementes de soja. Ciência e Agrotecnologia 32: 1126-1132.
Bered F, Carvalho FIF and Barbosa Neto JFB (2000) Variabilidade genética em trigo. Biotecnologia. Ciência e Desenvolvimento 14: 22-25.

Borges JM, Sabioni GS and Magalhães GFP (2006) A Universidade Federal de Viçosa no século XX. Editora UFV, Viçosa, 671p.

Brandão SS (1961) Contribuição ao estudo de cultivares de soja. Experientiae 1: 119-199.

Brito CH, Sediyama T, Teixeira RC, Paes JMV, Cardoso AA and Ferraz S (1999) Reação de linhagens de soja resistentes à raça 3 de Heterodera glycines quanto a Diaporthe phaseolorum f.sp. meridionalis e a Cercospora sojina. Revista Ceres 46: 159-174.

Capdeville G (1991) O ensino superior agrícola no Brasil. Universidade Federal de Viçosa, Viçosa, 184p.

Carvalho GA, Sediyama T, Marin ALA, Barros EG and Moreira MA(2002) Identificação de marcadores RAPD ligados a um gene de resistência ao cancro da haste da soja. Fitopatologia Brasileira 27: 474-478.

Cervigni GDL, Schuster I, Barros EG and Moreira MA (2004) Two microssatelite markers flanking a dominant gene for resistance to soybean cyst nematode race 3. Euphytica 135: 99-105.

Chiari L, Piovesan ND, Naoe LK, Viana JMS, Moreira MA and Barros EG (2004) Genetic parameters relating isoflavone and protein content in soybean seeds. Euphytica 138: 55-60.

Coelho FMG (1999) A construção das profissões agrárias. Universidade de Brasília, Brasília, 329p. (PhD Thesis).

Cunha GR (2001) Trigo no Brasil: História e tecnologia de produção. Embrapa, Passo Fundo, 208p.

Dias LAS (2011) Biofuel plant species and the contribution of genetic improvement. Crop Breeding and Applied Biotechnology S1: 16-26.

Diogo AM, Sediyama T, Lima RD and Sediyama CS (2000) Penetração e reprodução de Heterodera glycines, Raça 3, em algumas espécies vegetais. Nematologia Brasileira 24: 27-32.

Federizzi LC, Milach SCK, Barbosa Neto JF and Pacheco MT (1997) Melhoramento genético de trigo e aveia no Brasil. In Simpósio sobre Atualização em Genética e Melhoramento de Plantas. UFLA, Lavras, p. 127-146.

Freire MCM, Oliveira LO, Almeida AMR, Schuster I, Moreira MA, Liebenberg MM and Mienie CMS (2008) Evolutionary history of Phakopsora pachyrhizi (the Asian soybean rust) in Brazil based on nucleotide sequences of the internal transcribed spacer region of the nuclear ribossomal region. Genetics and Molecular Biology 31: $920-931$. 
Gravina GA, Sediyama CS, Martins Filho S, Moreira MA, Barros EG and Cruz CD (2004) Multivariate analysis of combining ability for soybean resistance to Cercospora sojina Hara. Genetics and Molecular Biology 27: 395-399.

Hartwig EE (1973) Varietal development. In Caldwell BE (ed.) Soybean: improvement, production, and uses. American Society of Agronomy, Madison, p. 187-210.

Lanna AC, José IC, Oliveira MGA, Barros EG and Moreira MA (2005) Effect of temperature on polyunsaturated fatty acid accumulation in soybean seeds. Brazilian Journal of Plant Physiology 17: 213-222.

MAPA - Ministério da Agricultura, Pecuária e Abastecimento (2012). Avaliable at $<$ http://extranet.agricultura.gov.br/php/snpc/cultivarweb/ cultivares_registradas.php $>$. Assessed in October, 2012.

Martins CAO, Sediyama CS, Oliveira MGA, Reis MS, Rocha VS and Moreira MA (2002) Resistance to stem canker, frogeye leaf spot and powdery mildew of soybean lines lacking lipoxygenases in the seeds. Scientia Agricola 59: 701-705.

Martins Filho S, Sediyama CS, Regazzi AJ and Peternelli LA (2002) Genetic analysis of soybean resistance to Cercospora sojina Hara. Crop Breeding and Applied Biotechnology 2: 549-556.

Mascarenhas HAA, Miranda MAC, Tisselli Filho O, Bulisani EA, Almeida LA and Braga NR (1983) Contribuição do Instituto Agronômico de Campinas na evolução da cultura da soja no Estado de São Paulo. Instituto Agronômico, Campinas, 50p. (Circular 32).

Matos JW (2005) Análise crítica do programa de melhoramento genético do feijoeiro da UFLA no período de 1974 a 2004. Universidade Federal de Lavras, Lavras, 116p. (PhD Thesis)

Matsuo E, Sediyama T, Cruz CD, Oliveira RDL, Oliveira RCT and Nogueira APO (2011) Genetic diversity in soybean genotypes with resistance to Heterodera glycines. Crop Breeding and Applied Biotechnology 11: 304-312.

Mello Filho OL (2006) Avaliação de cultivares e progênies de soja para a produção de silagem. Universidade Federal de Viçosa, Viçosa, 72p. (DSc Thesis).

Miyasaka S (1954) Melhoramento da soja. I. Observações preliminares sobre o comportamento de algumas cultivares de soja em São Paulo. Bragantia 14: 9-17.

Miyasaka S, Guimarães G, Kiihl RAS, Lovadini LAC and Demattê JD (1970) Variedades de soja indiferentes ao fotoperiodismo e tolerantes a baixa temperatura. Bragantia 29: 169-173.

Moraes RMA, Soares TCB, Colombo LR, Salla MFS, Barros JGA, Piovesan ND, Barros EG and Moreira MA (2006) Assisted selection by specific DNA markers for genetic elimination of the Kunitz trypsin inhibitor and lectin in soybean seeds. Euphytica 149: 221-226.

Moreira MA, Piovesan ND, Gesteira AS, Serretti C, Barros EG and Sediyama CS (1997) Genetic manipulation of soybean quality for the food industry. In Heller SR (ed.) V Conference in plant and animal genome. Scherago International, San Diego, p. 234.

Pereira M, Moreira MA, Rezende ST and Sediyama CS (1992) Efeitos de ácido linolênico, metil linoleato e trilinoleína na produção de compostos carbonílicos em extratos de soja. Arquivos Brasileiros de Biologia e Tecnologia 35: 403-419.

Santos EM, Piovesan ND, Barros EG and Moreira MA (2012) Low linolenic soybeans for biodiesel: characteristics, performance and advantages. Fuel, (http://dx.doi.org/10.1016/j.fuel.2012.06.014).

Schuster I, Abdelnoor RV, Marin SRR, Carvalho VP, Kiihl RAS, Silva JFV, Sediyama CS, Barros EG and Moreira MA (2001) Identification of a new major QTL associated with resistance to soybean cyst nematode (Heterodera glycines). Theoretical and Applied Genetics 102: 91-96.

Sediyama CS, Martins CAO, Oliveira MGA, Rocha VS, Reis MS and Moreira MA (2005) Efeito da eliminação genética das lipoxigenases sobre a qualidade fisiológica das sementes de soja em diferentes épocas de semeadura. Revista Ceres 52: 357-367.

Sediyama T, Pereira MG, Sediyama CS and Gomes JLL (1985) Cultura da soja - I Parte. Universidade Federal de Viçosa, Viçosa, 96p.

Sediyama T, Sediyama CS, Pereira MG, Oliveira AB, Gomes JLL, Reis MS, Dutra JH and Bhering MC (1983) Vinte anos de melhoramento de soja na Universidade Federal de Viçosa. Universidade Federal de Viçosa, Viçosa, 4p. (Folder)

Silva DB, Guerra AF, Rein TA, Anjos JRN, Alves RT, Rodrigues GC and Silva IAC (1996) Trigo para o abastecimento familiar: do plantio à mesa. Embrapa, Brasília, 176p.

Silva JG (1954) Variedades de soja para o Estado de São Paulo. Escola Superior de Agricultura "Luiz de Queiroz", Piracicaba, 34p. (DSc Thesis).

Souza GA (2011) Potencial de produção de silagem de híbridos de soja (Glycine max (L.) Merrill) obtidos por cruzamentos em dialelo. Universidade Federal de Viçosa, Viçosa, 62p. (DSc Thesis).

Swearingin ML and Sediyama T (1969a) 'Mineira' Nova variedade de soja para a região central do Brasil. Universidade Rural do Estado de Minas Gerais, Viçosa, 4p. (Folder)

Swearingin ML and Sediyama T (1969b) 'Viçoja' Nova variedade de soja para a região central do Brasil. Universidade Rural do Estado de Minas Gerais, Viçosa, 4p. (Folder)

Teixeira AI, Ribeiro LF, Rezende ST, Barros EG and Moreira MA (2012) Development of a method to quantify sucrose in soybean grains. Food Chemistry 130: 1134-1136.

Torres Filho A (1926) O ensino agrícola no Brasil: seu estado atual e a necessidade de sua reforma. Imprensa Nacional, Rio de Janeiro, 200p.

Utumi MM, Barros EG, Oliveira MGA, Sediyama CS and Moreira MA (1998) Efeito da eliminação genética de lipoxigenases e de polipeptídios de reserva na qualidade da proteína de soja. Revista Brasileira de Fisiologia Vegetal 10: 203-212.

Viegas GP and Krug CA(1952) Melhoramento do milho: II - Germoplasma utilizado nos trabalhos de seleção. Bragantia 12: 7-9.

Vieira C (1996) O Feijão e Eu - Memórias de um ex-aluno da ESAV. UFV, Divisão Gráfica Universitária, Viçosa, 178p.

Vieira C (2005) Memórias de meio século de estudos sobre a cultura do feijão. UFV, Divisão Gráfica Universitária, Viçosa, 214p.

Voysest O (1983) Variedades de frijol em America Latina y su origen. CIAT, Cali, 24p.

Williams LF (1955) A soja. Instituto Agronômico, Campinas, 36p. (Boletim 68).

Zimmermann MJO, Carneiro JES, Del Peloso MJ, Costa JGC, Rava CA and Sartorato A (1996) Melhoramento genético e cultivares. In Araújo RS, Rava CA, Stone LF and Zimmermann MJO (eds.) (1996) Cultura do feijoeiro comum no Brasil. Potafós, Piracicaba, p. 223-262. 